\title{
Perubahan Garis Pantai di Pesisir Cirebon Berdasarkan Analisis Spasial
}

\author{
AIDA HERIATI, SEMEIDI HUSRIN \\ Pusat Riset Kelautan, Badan Riset dan Sumber Daya Manusia Kelautan dan \\ Perikanan, Kementerian Kelautan dan Perikanan
}

Email: aidaheriati@yahoo.com

\begin{abstract}
ABSTRAK
Informasi kerusakan daerah Pesisir Utara Jawa bukan hal yang baru. Daerah pesisir Cirebon sebagai salah satu bagian Pesisir Utara Jawa mengalami permasalahan dinamika pesisir yang ditandai oleh erosi dan sedimentasi pantai. Erosi dan sedimentasi merupakan permasalahan mendasar dalam pengelolaan wilayah pesisir. Penelitian ini mengkaji kerusakan pesisir Cirebon ditinjau melalui perubahan garis pantai yang ditimbulkan oleh proses sedimentasi dan erosi yang terjadi secara alami ataupun akibat aktivitas manusia. Pengolahan data satelit Landsat tahun 1999 dan 2013 memberikan informasi sedimentasi dan erosi di sekitar pesisir Cirebon. Hasil perubahan garis pantai dari analisis satelit diverifikasi dengan pengamatan di lapangan dan wawancara dengan masyarakat pesisir yang dilakukan pada Juni 2013. Analisis memperlihatkan perubahan garis pantai di Pesisir Cirebon sangat dipengaruhi oleh aspek-aspek hidro-oseanografi, morfologi pantai, dan aktivitas manusia. Hasil ini diharapkan dapat menambah informasi mengenai kondisi pesisir di Cirebon yang dapat digunakan dasar dalam pengelolaan kerusakan wilayah pesisir sesuai dengan kondisi real di lapangan.
\end{abstract}

Kata kunci: Cirebon, garis pantai, erosi, akresi, pantura

\begin{abstract}
The damage of coastal area in Northen Java has been known for decades. As part of Northen Java Coastal, Cirebon coastal area suffered from severe damage due to erosion-abrasion phenomenon and turned to be a fundamental problem in coastal area management. This research analyses Cirebon coastal changes by analising shoreline changes induced by long term sedimentation and erosion processes. Landsat data in 1999 and 2013 are used in shoreline change analysis. The sattelite analysis results are verified by field observations and coastal communities interview in June 2013. The results show that the coastline dynamics of Cirebon are strongly influenced by hydro-oceanography aspects, coastal morphology and human activities. This result provides valuable information on the latest conditions of coastal area in Cirebon and this can be used as basis for land use management and future mitigation of costal areas.
\end{abstract}

Keywords: Cirebon, coastlines, erosion, accretion, pantura 


\section{PENDAHULUAN}

Pantai berlumpur merupakan tipe pantai yang mendominasi di sepanjang pesisir Kabupaten Cirebon. Tipe pantai lainnya yaitu pantai berpasir dan berhutan bakau. Muara-muara sungai yang terdapat di sepanjang pesisir ini menyebabkan sedimentasi tinggi, sehingga merubah garis pantai di daerah tersebut terutama di kawasan pantai timur Cirebon (Astjario dan Harkins, 2005). Rohman (2012) melakukan pembobotan indeks kerentanan pesisir berdasarkan karakteristik gelombang dari hasil pemodelan di beberapa kecamatan di Cirebon. Hasilnya menunjukkan Kecamatan Lemahwungkuk termasuk kecamatan yang kurang rentan akan peristiwa abrasi, sedangkan kecamatan lainnya (Kecamatan Kapetakan, Suranenggala, Gunung Jati, Kejaksaan, Mundu, Astanajapura, Pangenan, Gebang, dan Losari) termasuk yang rentan akan abrasi.

Pemodelan gelombang menggunakan Simulating Waves Nearshore (SWAN) memprediksi tinggi signifikan gelombang maksimum di perairan Cirebon sebesar 0,68 $\mathrm{m}$ dengan rata-rata tinggi gelombang signifikan adalah 0,229 m. Dominan arah gelombang di musim timur adalah Barat-Barat Laut dan di musim barat adalah Tenggara-Selatan, serta periode gelombang maksimum sebesar 5,56 detik (Rohman, 2012). Hasil simulasi model hidrodinamika menunjukkan bahwa sirkulasi arus di perairan Cirebon dipengaruhi oleh kondisi musiman (Suciaty dan Rizki, 2012). Kondisi angin musiman di perairan tersebut dominan berhembus dari Barat Laut pada bulan Januari dan Tenggara pada bulan Agustus. Analisis harmonik menunjukkan bahwa arus pasang surut bergerak ke arah Barat Laut-Utara (pasang) dan Tenggara-Selatan (surut) dengan kecepatan maksimum rata-rata sebesar 0,2 $\mathrm{m} /$ det dan arahnya 336,6 derajat (Siswanto, 2008). Adapun kecepatan maksimum rata-rata arus non pasut adalah $0.28 \mathrm{~m} /$ det dengan arah 341 derajat.

Astjario dan Harkins (2005) berpendapat bahwa proses bertambahnya daratan, perubahan garis pantai, dan tanah timbul dapat terjadi akibat pola arus sejajar garis pantai (Iongshore current) dan pola arus laut (offshore current). Aktivitas hidro-oseanografi tersebut mengakibatkan material sedimen terendapkan di sekitar garis pantai dan muara sungai. Menurut Hanafi (2013), garis pantai umumnya mengalami perubahan dari waktu ke waktu sejalan dengan perubahan alam seperti adanya aktivitas gelombang, angin, pasang surut dan arus, serta sedimentasi daerah delta sungai. Perubahan garis pantai juga terjadi akibat gangguan ekosistem pantai seperti pembuatan tanggul dan kanal serta bangunan-bangunan yang ada di sekitar pantai. Hutan bakau sebagai penyangga pantai banyak diubah fungsinya untuk dijadikan sebagai daerah pertambakan, hunian, industri, dan daerah reklamasi yang mengakibatkan terjadinya perubahan garis pantai. Perubahan garis pantai dapat dikaji melalui teknik interpretasi citra satelit. Zhao, dkk. (2008) dalam Kasim (2012) menerangkan bahwa teknik interpretasi citra satelit dapat memonitor cakupan wilayah yang luas dengan pengulangan, serta menyediakan data multitemporal.

Penelitian ini menganalisis perubahan garis pantai di pesisir Cirebon dengan berbasis data citra satelit dan pengukuran di lapangan. Perubahan garis pantai dianalisis secara spasial dengan memanfaatkan data satelit multitahun, sehingga didapatkan informasi perubahan garis pantai temporal, kemudian hasilnya divalidasi dengan data pengukuran lapangan. Hasil analisisnya dapat digunakan oleh pemerintah setempat sebagai dasar dalam pengambilan keputusan terkait pengelolaan wilayah pesisir Cirebon. 


\section{METODOLOGI}

\subsection{Tempat dan Waktu Penelitian}

Penelitian ini dilakukan di pesisir Cirebon, Jawa Barat terutama pada Kecamatan pesisir Cirebon yang pengelolaannya termasuk wilayah Kabupaten Cirebon dan Kota Cirebon (gambar 1). Analisis dilakukan dengan menggunakan data satelit Landsat dengan dua waktu berbeda yaitu tahun 1999 dan 2013. Hasil pengolahan dari data satelit tersebut kemudian divalidasi dengan data survei lapangan yang dilakukan antara tanggal 10-15 Juni 2013. Survei lapangan dilengkapi dengan wawancara bersama para penduduk yang ditemui di lokasi penelitian setelah sebelumnya melakukan Forum Group Discussion (FGD) di bulan Mei 2013. FGD dilakukan dengan beberapa instansi terkait wilayah pesisir, seperti Dinas Kelautan dan Perikanan Kota Cirebon, Dinas Kelautan dan Perikanan Kabupaten Cirebon, Loka Serang KP3K, BAPPEDA Kota/Kab. Cirebon, Balai Besar Wilayah Sungai (BBWS) CimanukCisanggarung, Konsultan swasta (ASR), serta Perwakilan dari kantor Puslitbang Sumber daya laut dan pesisir.

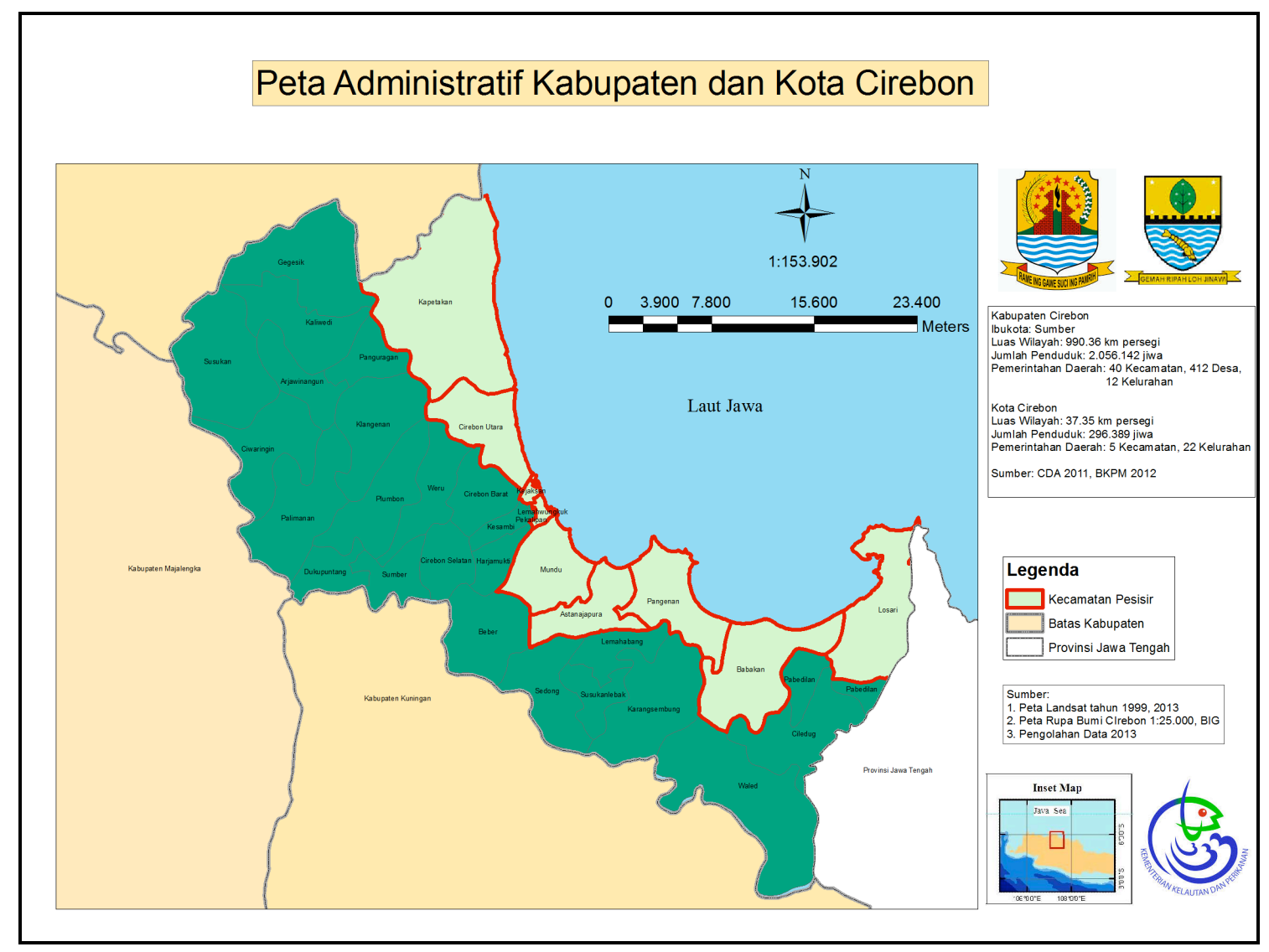

Gambar 1. Peta Administratif Kabupaten dan Kecamatan Pesisir Cirebon

\subsection{Bahan dan Data}

Kerangka kerja dari penelitian ini diperlihatkan pada gambar 2 dan berbagai kegiatan yang dilakukan ditunjukkan di tabel 1. Data Landsat pada dua tahun yang berbeda (1999 dan 2013) dikoreksi, kemudian dilakukan composite RGB dan digitasi. Proses digitasi mengubah data raster (satelit) menjadi data vektor, sehingga perubahan garis pantai di lokasi penelitian diketahui. Metode overlay antara dua data citra dilakukan untuk menganalisis perubahan garis pantai yang terjadi selama 14 tahun pengamatan. Kemudian dilakukan perhitungan terhadap perubahan area erosi/sedimentasi dan laju perubahannya di lokasi penelitian. 


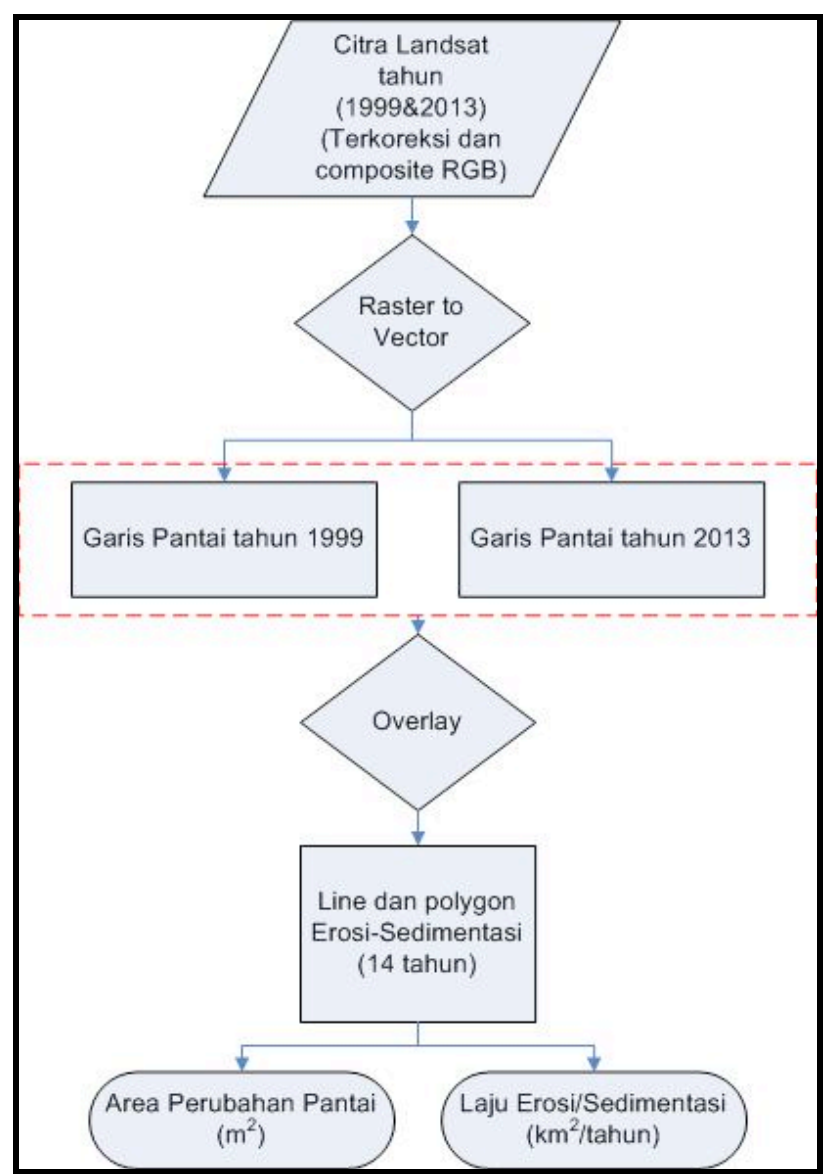

Gambar 2. Diagram Alir Penelitian

Tabel 1. Kegiatan Pengumpulan Data dan Informasi yang Diperoleh

\begin{tabular}{ll}
\hline \multicolumn{1}{c}{ Kegiatan pengumpulan data } & \multicolumn{1}{c}{ Informasi yang diperoleh } \\
\hline Data Landsat & Perubahan garis pantai dari hasil digitasi \\
\hline Observasi Lapangan & $\begin{array}{l}\text { Dokumentasi mengenai kondisi terkini dan fenomena yang terjadi di } \\
\text { lokasi penelitian }\end{array}$ \\
\hline Wawancara dengan pihak terkait & $\begin{array}{l}\text { Informasi mengenai kondisi lokasi penelitian pada tahun-tahun } \\
\text { sebelumnya dan kondisi terkini }\end{array}$ \\
\hline Studi Literatur & Publikasi penelitian dan kondisi yang terjadi di pesisir Cirebon \\
\hline
\end{tabular}

\subsection{Analisis Data}

Analisis data untuk mengetahui perubahan garis pantai di lokasi penelitian mencakup analisis data hasil citra dan hasil survei lapangan. Hasil overlay dari kedua garis pantai dalam citra memberikan informasi perubahan area yang terjadi, termasuk perhitungan laju erosi/sedimentasi. Adapun hasil survei lapangan digunakan untuk mendukung hasil pengolahan data satelit tersebut. Survei lapangan dilakukan dengan melakukan penyusuran di sepanjang pesisir Cirebon dan mengambil titik pengamatan di lapangan sesuai informasi dari hasil pengolahan data satelit. 


\section{HASIL DAN PEMBAHASAN}

\subsection{Hasil Analisis Perubahan Garis Pantai}

Dari hasil pengolahan data citra diperoleh informasi bahwa sepanjang pesisir Cirebon mengalami fenomena erosi dan sedimentasi (gambar 3). Lokasi-lokasi yang mengalami fenomena erosi ditandai dengan warna merah yang terjadi di Kecamatan Kapetakan (sebelah barat), Cirebon Utara, sebelah timur Pangenan, dan sebelah timur Losari. Adapun proses sedimentasi yang ditandai dengan warna biru terjadi di Kecamatan Kapetakan di bagian timur, Kejaksan, Lemahwungkuk, Mundu, Astanajapura, dan Pangenan. Wilayah pesisir barat Cirebon cenderung lebih stabil dan mengalami lebih sedikit perubahan garis pantai dibandingkan dengan pesisir timur Cirebon.

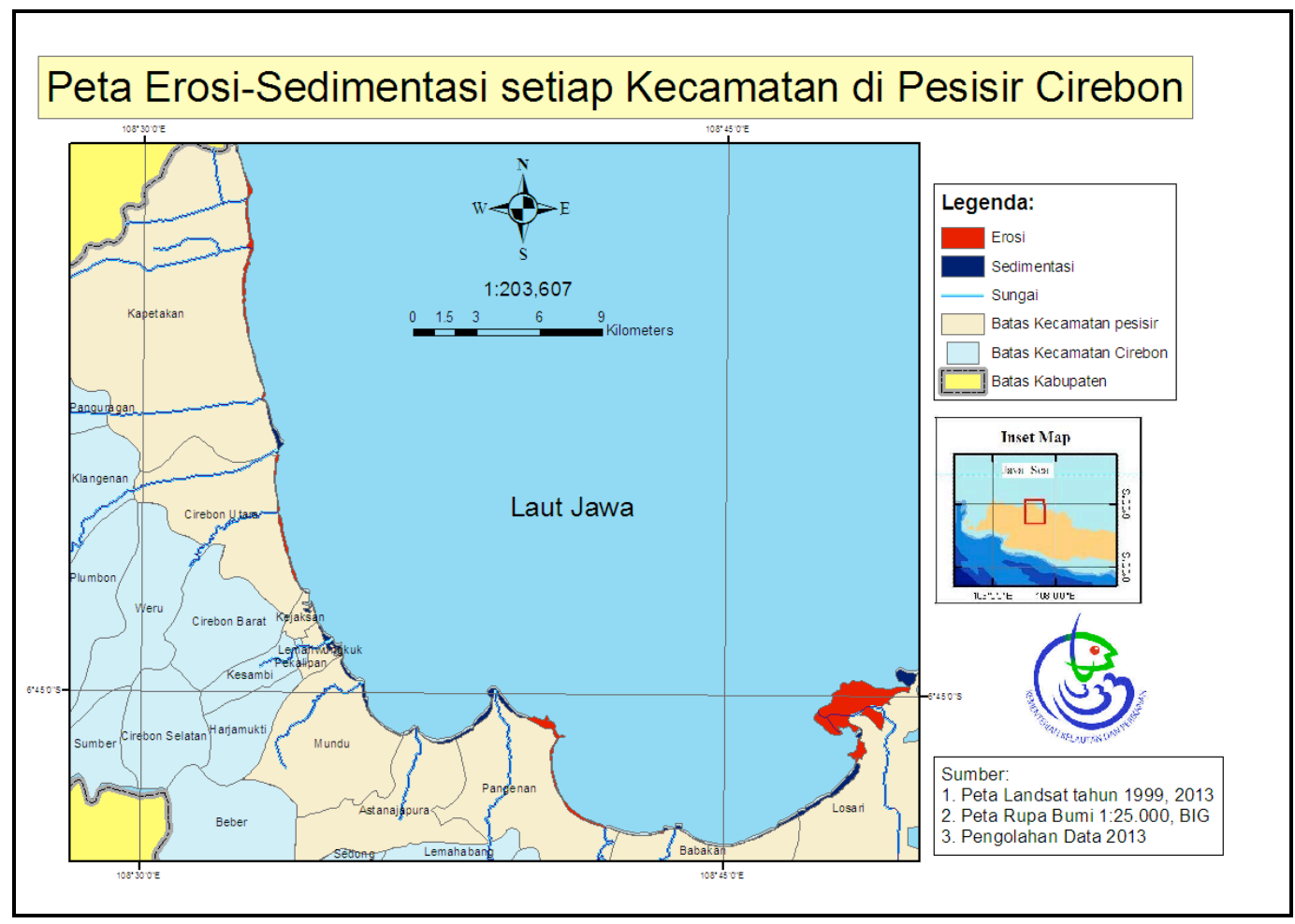

Gambar 3. Perubahan Garis Pantai di Sepanjang Pesisir Cirebon

Besarnya area perubahan erosi/sedimentasi ditunjukkan pada tabel 2 dan 3 . Hasil pengolahan data citra menunjukkan area terbesar yang mengalami erosi adalah Kecamatan Losari yang merupakan kecamatan pesisir terluas kedua setelah Kecamatan Cirebon Utara (tabel 2). Luas erosi yang terjadi di Kecamatan Losari sebesar $6 \mathrm{~km}^{2}$ dan luas erosi kedua terbesar adalah Kecamatan Kapetakan dengan luar area erosi sebesar 0,97 $\mathrm{km}^{2}$. Laju erosi tertinggi terjadi di Kecamatan Losari dengan laju erosi $0,43 \mathrm{~km}^{2} /$ tahun dan laju erosi terendah dialami Kecamatan Lemahwungkuk sebesar 0,00049 km²/tahun.

Kecamatan Losari juga mengalami sedimentasi dan luasan area sedimentasinya selama 14 tahun pengamatan adalah sebesar $1,26 \mathrm{~km}^{2}$, serta laju sedimentasi tertinggi sebesar 0,09 $\mathrm{km}^{2}$. Area kedua terbesar yang mengalami perubahan luasan pantai akibat sedimentasi adalah Kecamatan Pangenan dengan besar luasan perubahan sebesar 0,87 $\mathrm{km}^{2}$. Kecamatan Cirebon Utara merupakan kecamatan yang mengalami laju sedimentasi terendah sebesar 0,00046 km²/tahun (tabel 3). 
Tabel 2. Tabel Area Erosi di Sepanjang Kecamatan Pesisir Cirebon

\begin{tabular}{|c|l|c|c|c|}
\hline No & Nama Kecamatan & Luas Wilayah $\mathbf{( k m}^{\mathbf{}} \mathbf{)}$ & Luas Erosi $\mathbf{( k m}^{\mathbf{2}} \mathbf{)}$ & $\begin{array}{c}\text { Laju Erosi } \\
(\mathbf{k m} \text { / } \mathbf{\text { thn }})\end{array}$ \\
\hline 1 & Astanajapura & 25,47 & 0,01438 & 0,00103 \\
\hline 2 & Babakan & 21,93 & 0,12113 & 0,00865 \\
\hline 3 & Cirebon Utara & 43,53 & 0,53312 & 0,03808 \\
\hline 4 & Kapetakan & 60,2 & 0,97055 & 0,06932 \\
\hline 5 & Kejaksan & 3,616 & 0,01509 & 0,00108 \\
\hline $\mathbf{6}$ & Lemahwungkuk & $\mathbf{6 , 5 0 7}$ & $\mathbf{0 , 0 0 6 9 3}$ & $\mathbf{0 , 0 0 0 4 9}$ \\
\hline 7 & Losari & 39,07 & 6,02476 & 0,43034 \\
\hline 8 & Mundu & 25,58 & 0,03798 & 0,00271 \\
\hline 9 & Pangenan & 30,54 & 0,94794 & 0,06771 \\
\hline & Total & 233,463 & 8,67188 & \\
\hline
\end{tabular}

Tabel 3. Tabel Area Sedimentasi di Sepanjang Kecamatan Pesisir Cirebon

\begin{tabular}{|c|l|c|c|c|}
\hline No & Nama Kecamatan & $\begin{array}{c}\text { Luas Wilayah } \\
\left(\mathbf{k m}^{\mathbf{2}} \mathbf{)}\right.\end{array}$ & $\begin{array}{c}\text { Luas Sedimentasi } \\
\mathbf{( k m}^{\mathbf{2}} \mathbf{)}\end{array}$ & $\begin{array}{c}\text { Luas Sedimentasi } \\
\mathbf{( k m}^{\mathbf{2}} \mathbf{/ t h} \mathbf{)}\end{array}$ \\
\hline 1 & Astanajapura & 25,47 & 0,02766 & 0,00198 \\
\hline 2 & Babakan & 21,93 & 0,26485 & 0,01892 \\
\hline $\mathbf{3}$ & Cirebon Utara & $\mathbf{4 3 , 5 3}$ & $\mathbf{0 , 0 0 6 4 6}$ & $\mathbf{0 , 0 0 0 4 6}$ \\
\hline 4 & Kapetakan & 60,2 & 0,36481 & 0,02606 \\
\hline 5 & Kejaksan & 3,616 & 0,08512 & 0,00608 \\
\hline 6 & Lemahwungkuk & 6,507 & 0,32279 & 0,02306 \\
\hline 7 & Losari & 39,07 & 1,26198 & 0,09014 \\
\hline 8 & Mundu & 25,58 & 0,31127 & 0,02223 \\
\hline 9 & Pangenan & 30,54 & 0,87417 & 0,06244 \\
\hline & Total & 233,463 & 3,51913 & \\
\hline
\end{tabular}

\subsection{Hasil Analisis Survei Lapangan}

Survei lapangan dilakukan pada tanggal 10-15 Juni 2013 dengan melakukan penyusuran di sepanjang pesisir Cirebon (gambar 4). Lokasi survei meliputi daerah, Kasepuhan (C1), Kebon Baru (C2-C3), Pasindayan (C4), Klayan (C5-C6), Karang Sembung (C7), Kalijaga (C8), Kalimundu (C9), Pangenan (C10) dan Gebang (C11).

Lokasi pengamatan paling timur Cirebon adalah Karang Sembung (C7). Lokasi pengamatan cukup sulit dijangkau, sehingga digunakan roda dua untuk mencapainya. Daerah ini didominasi oleh tambak. Beberapa vegetasi mangrove berada di wilayah bertipe irigasi, sedangkan yang lainnya di wilayah bertipe kombinasi yang digunakan untuk persawahan. Perairan ini cukup dangkal bila melihat dari karakteristik gelombang yang pecah jauh dari garis pantai. Air terlihat keruh namun sampah tak banyak terlihat seperti di perairan lainnya.

Daerah Klayan (C5-C6) merupakan titik pengamatan yang terkena erosi. Salah satu responden yang ditemui mengungkapkan bahwa selama 2 bulan terakhir dua kolam yang digunakan untuk membudidayakan udang (Kolam Udang) dan belum dipanen telah rusak terkena erosi. Selain itu, tambak bandeng (1 petak/balong lebarnya sekitar 30-40 m dan panjang lebih dari ratusan meter) sekitar jarak $160 \mathrm{~m}$ juga rusak karena erosi sampai dengan daerah Tangkil. Di daerah Pasindayan (C4) terlihat mangrove jenis Rhizopora, bakau yang masih muda dan rumput-rumputan. Terlihat juga adanya pelindung pantai yang dibuat berlapis dengan beda ketinggian diperkirakan gelombang turun sekitar $300 \mathrm{~m}$ dari breakwater. Di lokasi ini banyak terdapat sampah dan jalan berlumpur sehingga sulit untuk diakses. Dibelakang pantai terdapat tambak udang dan bandeng. Daerah Kebon Baru (C2- 
C3) lokasinya berdekatan dengan pelabuhan dan Tempat Pelelangan Ikan (TPI). Banyak terlihat adanya sampah yang diduga berasal dari aliran sungai serta terlihat pula pecahanpecahan dari cangkang kerang.

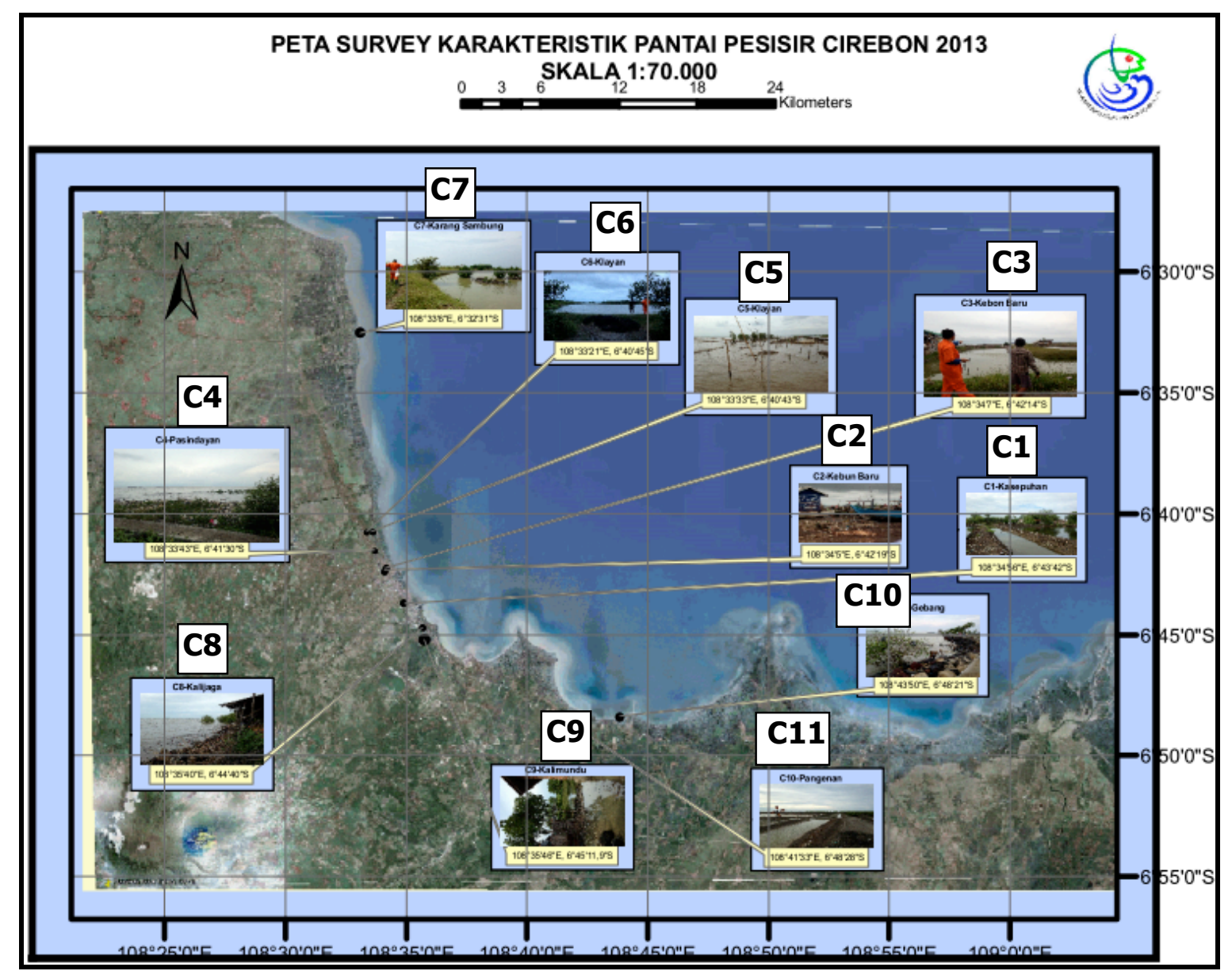

\section{Gambar 4. Peta Karakteristik Pantai Pesisir Cirebon Hasil Survei Lapangan Tahun 2013 (Sumber: dimodifikasi dari Google_earth 2009)}

Tanah timbul terjadi di lokasi pengamatan daerah Kasepuhan (C1). Penduduk setempat yang diwawancarai menjelaskan garis pantai dahulu sekarang merupakan ujung dari perumahan yang ada saat ini. Di lokasi ini juga terjadi penumpukan sampah dan akhirnya dijadikan empang oleh masyarakat serta ditanami pohon berjenis api-api. Keadaan seperti ini berlanjut sampai ke Mundu. Pembuatan sertifikat di lokasi tanah timbul dapat dilakukan sesuai jika dengan yang sudah ditentukan. Lokasi yang didatangi saat pengamatan lapangan di Mundu diperuntukkan untuk pemancingan. Lokasi pengamatan di daerah Kalijaga (C8) merupakan pesisir dengan jenis pasir berwarna kehitaman namun airnya tidak begitu keruh serta sampah organik banyak terlihat di lokasi tersebut. Terlihat pula adanya bekas-bekas pohon akibat erosi. Daerah Kalimundu (C9) merupakan pesisir dengan jenis yang berpasir serta berlumpur. Jenis mangrove yang banyak terlihat adalah jenis api-api, terlihat pula ke arah laut beberapa hasil kegiatan penanaman mangrove, hanya saja saat ombak besar akarnya ikut tercabut. Hasil wawancara penduduk setempat menyebutkan bahwa daerah tersebut mengalami sedimentasi kurang lebih $400 \mathrm{~m}$, namun saat pasang pun terkena rendaman air sampai ke perumahan penduduk. Ombak besar biasa terjadi saat angin timur. 
Peruntukan lahan tambak garam terlihat di daerah Pangenan (C10). Hasil wawancara menyebutkan bahwa lokasi ini sudah sejak dulu merupakan tambak garam, pantai mulai terabrasi sejak 2010 akibat ombak yang besar dan saat kondisi pasang air laut sampai merendam tambak garam. Area di bagian depan yang menghadap ke laut terlindungi oleh mangrove berjenis api-api dan di belakang mangrove terdapat pula tambak udang. Di sekitaran pantai daerah Gebang (C11) terlihat adanya pelindung pantai sehingga kondisi pesisir cukup aman dari erosi-sedimentasi, kondisi air tidak terlalu keruh dan cukup terjaga kebersihannya, sedangkan pasir berwarna hitam legam. Di sekitar pantai terlihat ada pabrik es dan TPI, serta menuju jalan masuk dari jalan raya terdapat pasar ikan. Umumnya, perahu nelayan ditambatkan di sekitar sungai dan terlihat pula kondisi perumahan nelayan sekitarnya sudah sangat memadai.

\subsection{Pembahasan}

Hasil pengamatan citra satelit selama 14 tahun menunjukkan perubahan garis pantai pesisir barat Cirebon mengalami fenomena erosi-sedimentasi lebih kecil dibandingkan daerah pesisir timur Cirebon. Hasil ini menguatkan penelitian dari Astjario dan Harkins (2005) yang juga menyebutkan bahwa kondisi pesisir sebelah barat Cirebon cenderung lebih stabil. Tipe pantai di perairan tersebut yang menyebabkan kondisi daerah pesisir barat memiliki tipe pantai berpasir dan sebelah timurnya memiliki tipe pantai berlumpur. Sesuai dengan karakteristik dari sedimen dimana tipe pantai berlumpur memiliki tingkat kerentanan yang lebih tinggi sehingga dapat mudah terangkut oleh arus.

Perhitungan terhadap area luasan perubahan garis pantai menunjukkan Kecamatan Losari dan Kecamatan Cirebon Utara memiliki nilai cukup tinggi. Wilayah-wilayah ini juga memiliki laju erosi dan sedimentasi yang tinggi juga, yaitu laju erosi $0,4 \mathrm{~km}^{2} /$ thn dan laju sedimentasi $0,09 \mathrm{~km}^{2} /$ thn. Hal ini dapat terjadi dikarenakan tipe pantai yang berlumpur dan kondisi arus yang terjadi di daerah tersebut, dimana pola arus bergerak menjauhi pantai dan gelombang dominan bergerak menuju Barat-Barat Laut (Astjario dan Harkins, 2005). Kecamatan Lemahwungkuk mengalami laju erosi terendah dibandingkan daerah lainnya dan hasil ini berkesesuaian dengan indeks kerentanan berdasarkan karakteristik gelombang yang dilakukan oleh Rohman (2012), yaitu Kecamatan Lemahwungkuk memiliki indeks kurang rentan akan bahaya erosi.

Penanganan bahaya akan terjadinya erosi-sedimentasi dapat dilakukan dengan melakukan penanganan dalam bentuk fisik melalui teknik soft structure. Teknik ini lebih diutamakan dikarenakan sifatnya yang lebih alami serta tidak memerlukan biaya yang besar dibandingkan dengan hard structure. Hard structure cenderung mahal akan tetapi tidak menyelesaikan masalah pesisir dan hanya bersifat memindahkan masalah yang ada. Selain itu, perlu adanya penguatan kebijakan baik dalam hal penyusunannya yang dilandasi dengan kondisi ilmiah hasil penelitian, penerapan kebijakannya secara menyeluruh, serta penguatan dalam penyelenggaraannya. Koordinasi antarinstansi juga diperlukan dalam melakukan pembahasan dan perencanaan yang baik dalam menanggulangi masalah erosi-sedimentasi. Koordinasi ini akan dapat menanggulangi masalah secara lebih menyeluruh dan tidak adanya tumpang tindih serta kekosongan dalam pengerjaannya. Diversifikasi usaha dan penyuluhan masyarakat juga diperlukan mengingat hilangnya atau berubahnya lahan tempatnya bekerja akan menyebabkan berubah pula mata pencaharian. Sehingga, pengalihan pekerjaan dan pemahaman masyarakat akan pentingnya menjaga kelestarian alam sangatlah diperlukan untuk mengurangi dampak dari masalah erosi-sedimentasi yang terjadi di daerah tersebut. 


\section{KESIMPULAN DAN SARAN}

\subsection{Kesimpulan}

Hasil analisis citra satelit menunjukkan laju erosi dan sedimentasi tertinggi terjadi di Kecamatan Losari dengan besar laju erosi adalah $0,4 \mathrm{~km}^{2} /$ tahun dan laju sedimentasi $0.09 \mathrm{~km}^{2} /$ tahun. Laju erosi terendah dialami Kecamatan Lemahwungkuk (490 m²/tahun) sedangkan laju sedimentasi terendah terdapat di Kecamatan Cirebon Utara (460 $\mathrm{m}^{2}$ /tahun). Karakteristik pantai yang berlumpur serta pola arus dan arah gelombang yang dominan menyebabkan Kecamatan Losari rentan akan bahaya erosi-sedimentasi. Penanganan perubahan kondisi perairan ini haruslah segera dilakukan agar kesetimbangan ekosistem dapat terus terjaga. Proses erosi-sedimentasi yang terjadi di pesisir Cirebon disebabkan oleh pola arus laut dan sejajar pantainya yang terjadi, kondisi gelombang, tipe pantai, serta kondisi pantainya.

\subsection{Saran}

Untuk penelitian selanjutnya diharapkan dapat melakukan perhitungan jarak perubahan garis pantai di setiap kecamatan dengan mempertimbangkan fungsi lahan di daerah tersebut. Perlu dilakukan pula kajian lebih lanjut mengenai penanganan erosisedimentasi di daerah pesisir Cirebon baik secara fisik maupun non fisik.

\section{UCAPAN TERIMA KASIH}

Penulis mengucapkan banyak terima kasih kepda pihak-pihak yang telah banyak membantu dalam penelitian ini. Data lapangan diperoleh dari DIPA tahun 2013 kegiatan Loka Penelitian Sumber Daya dan Kerentanan Pesisir (LPSDKP), Balitbang Kelautan dan PerikananKementerian Kelautan dan Perikanan

\section{DAFTAR PUSTAKA}

Astjario, P. dan Harkins, FX. (2005). Penelitian Lingkungan Pantai Wilayah Pesisir Kabupaten Cirebon, Jawa Barat. Vol.3, No. 2, 2005.

Hanafi, M. (2013). Studi Perubahan Garis Pantai Kaitannya dengan Pengelolaan Wilayah Pesisir Indramayu Jawa Barat, Puslitbang Geologi Kelautan. Dipetik 22 Oktober, 2013, dari http://mgi.esdm.go.id/content/studi-perubahan-garis-pantai-kaitannya-denganpengelolaan-wilayah-pesisir-indramayu-jawa-jar.

Kasim, F. (2012). Pendekatan Beberapa Metode dalam Monitoring Perubahan Garis Pantai Menggunakan Dataset Penginderaan Jauh Landsat dan SIG. Jurnal IImiah Agropolitan: 5(1).

Rohman, I. A. (2012). Pemetaan Gelombang Laut dengan Metode Pemodelan Numerik dan Pemanfaatannya untuk Mengidentifikasi Kerentanan Wilayah Pesisir terhadap Abrasi (Wilayah Studi: Kabupaten dan Kota Cirebon). Tugas Akhir Sarjana Institut Teknologi Bandung. Bandung.

Siswanto, H. (2008). Analisis Arus di Perairan Pantai Desa Kanci, Cirebon. Tugas Akhir Sarjana Institut Teknologi Bandung. Bandung.

Suciaty, F. dan Rizki, T.Y. (2012). Coastal Oceanographic Modelling Studies of Coastal Erosion Problem along The Coast of Indramayu-Cirebon. Prosiding "The Second International Conference on Port, Coastal, and Offshore Engineering (2nd ICPCO)", Bandung, 12-13 November 2012. 